\title{
Extension of Ratio System Part of MOORA Method for Solving Decision-Making Problems with Interval Data
}

\author{
Dragisa STANUJKIC, Nedeljko MAGDALINOVIC, \\ Sanja STOJANOVIC, Rodoljub JOVANOVIC \\ Faculty of Management Zajecar, Megatrend University \\ Park Suma "Kraljevica” bb, 19000 Zajecar, Serbia \\ e-mail:dragisa.stanujkic@fmz.edu.rs,nedeljko.magdalinovic@fmz.edu.rs, \\ sanja.stojanovic@fmz.edu.rs,rodoljub.jovanovic@fmz.edu.rs
}

Received: July 2011; accepted: October 2011

\begin{abstract}
In some cases of using multi-criteria decision making methods for solving real-world problems ratings of alternatives cannot be determined precisely, and that is why they are expressed in the form of intervals. Therefore, the aim of this paper is to extend the MOORA method for solving decision making problems with interval data. By extending the ratio system part of MOORA method, an algorithm to determine the most preferable alternative among all possible alternatives, when performance ratings are given as intervals, is presented. Finally, an example is shown to highlight the proposed procedure, at the end of this paper.
\end{abstract}

Keywords: multi-criteria decision making, MOORA, ratio system, uncertainty, interval fuzzy numbers.

\section{Introduction}

The multi-criteria decision making (MCDM) can be generally described as the process of selecting one from a set of available alternatives, which meets the objectives of choice most efficiently. In the multi-criteria decision making, problems can be classified as multi-objective or multi-attribute problems. This classification is based on the number of alternatives in a given problem. When the decision space is continuous, multiobjective decision making (MODM) methods are used, while multi-attribute decision making (MADM) involves selecting the best alternative among a finite number of predetermined alternatives.

In a number of published papers, different authors propose several ways for decomposition of MADM process and thereby identify the different stages and different number of stages (Jahanshahloo et al., 2006b) in this process. In the simplest form of decomposition, MADM can be divided into four stages: (1) identification and formulation of the problem; (2) construction of MADM model; (3) normalization stage; (4) aggregation stage; and (5) choice. 
The MADM process begins with the identification of the problem followed by its formulation. Over the first stage of this process: objectives/goals to be achieved, set of available alternatives, set of relevant criteria/attributes and their weights are defined. As a consequence of performing these activities the initial decision-making matrix can be constructed, as shown below:

$$
\begin{aligned}
& \begin{array}{llll}
C_{1} & C_{2} & \ldots & C_{n}
\end{array} \\
& D=\begin{array}{c}
A_{1} \\
A_{2} \\
\vdots \\
A_{m}
\end{array}\left[\begin{array}{cccc}
x_{11} & x_{12} & \ldots & x_{1 n} \\
x_{12} & x_{22} & \ldots & x_{2 n} \\
\vdots & \vdots & \vdots & \vdots \\
x_{1 n} & x_{2 n} & \ldots & x_{m n}
\end{array}\right], \\
& W=\left[w_{1}, w_{2}, \ldots, w_{n}\right],
\end{aligned}
$$

where $A_{1}, A_{2}, \ldots, A_{m}$ are available alternatives, $C_{1}, C_{2}, \ldots, C_{n}$ are criteria, $x_{i j}$ is performance rating of $i$ th alternative with respect to $j$ th criterion/attribute, $w_{j}$ is weight (significance) of $j$ th criterion, $m$ is the number of alternatives, and $n$ is the number of criteria.

At the same time, during construction of a decision-making matrix, the corresponding MADM model is also formed.

In MADM models, ratings for different criteria are usually expressed by using different units of measures. In order to transform various units into dimensionless comparable units, the normalization procedure is used.

The next stage in MADM is the aggregation stage. The purpose of this stage is to transform the multi-criteria problem in the corresponding single-criterion problem (Guo and Tanaka, 2000). Aggregation procedure, which performs the specified transformation, collects the information available in decision-making matrix, ratings and weights, in the overall performance index, for each alternative.

In the final stage of MADM, on the basis of the overall performance indexes, ranking or selecting the most appropriate alternative, from available alternatives, can be done.

The most preferable conditions for using the multi-attribute decision making is when all ratings and weights are known precisely. Based on this subject, literature proposes several MADM methods that can be applied under the above mentioned conditions, the so called classical MADM methods. The concise overview of these methods, their characteristics and applicability are presented in Hwang and Yoon (1981), Triantaphyllou and Lin (1996) and Yoon and Hwang (1995). As a widely used the following MADM methods can be stated: Simple Additive Weighting (SAW) method (MacCrimon 1968), Technique for Ordering Preference by Similarity to Ideal Solution (TOPSIS) method (Hwang and Yoon, 1981), Analytic Hierarchy Process (AHP) method (Saaty, 1980), ELimination and Choice Expressing REality (ELECTRE) method (Roy, 1991), Preference Ranking Organisation Method for Enrichment Evaluations (PROMETHEE) method (Brans and Vincke, 1985), COmplex PRoportional ASsessment (COPRAS) method (Zavadskas et al., 1994, 2009a; Kaklauskas et al., 2010), VIKOR (VIsekriterijumska optimizacija i KOmpromisno Resenje - in Serbian) method (Opricovic, 1998), a newly-proposed Additive Ratio Assessment (ARAS) method (Zavadskas and Turskis, 2010; Zavadskas et al., 2010a) and many years applied Game theory (Peldschus et al., 2010, 2009). 
However, many real-world decision making problems take place in environments in which the ratings and weights are not known precisely. In such environments classical MADM methods, which use crisp numbers to express the ratings and weights, do not provide adequate and effective decision making.

The use of inaccurate or unreliable data, i.e., performances and/or weights, also require the use of some form of fuzzy or interval numbers. Bellman and Zadeh (1970) were the first researchers in the field of decision making using fuzzy sets, who also initiated the fuzzy multi-attribute decision making (FMADM) methodology. FMADM methodology is developed to resolve the lack of precision in assigning weights of criteria/attributes and the ratings of alternatives regarding evaluation criteria (Chen and Klein, 1997). This approach helps decision makers to solve complex decision making problems in a systematic, consistent and productive way (Carlsson and Fuller, 1996). Therefore, the ability and application of multi-attribute methods with fuzzy set theory has been published in many professional journals in various disciplines (Wang and Chang, 2007).

Classical MADM methods do not have the ability to use fuzzy numbers. In order to extend their application with fuzzy numbers, two options are available: (1) the transformation of fuzzy numbers into crisp numbers, before performing the aggregation stage; or (2) extension of the classical MADM methods, with the aim of using fuzzy numbers.

The use and transformation of fuzzy numbers into crisp numbers in earlier stages of MADM process does not provide significant benefits. More benefits from the use of fuzzy numbers can be achieved if they are transformed into crisp numbers in the later stages of MADM process.

The use of fuzzy numbers in the later stages of fuzzy MADM process requires the use of aggregation procedures that also have the ability to perform arithmetic operations on fuzzy numbers. Therefore, it is necessary that the aggregation procedure used in fuzzy MADM methods implement the extension principle (Zadeh, 1965) to determine the overall performances. As a result of performing operations on fuzzy numbers, overall performances are still fuzzy numbers. Therefore, fuzzy MADM methods must also be able to perform the ranking of alternatives on the basis of fuzzy overall ratings, or perform their defuzzification before performing ranking. For this purpose, different methods are proposed such as: $\alpha$-cut concept (Buckley and Qu, 1990), Vertex method (Dong and Shah, 1987; Chen, 2000) and Best Nonfuzzy Performance (Opricovic and Tzeng, 2003).

The ability to solve many real-world decision making problems has led to the development of fuzzy extensions of some known MADM methods, such as SAW, TOPSIS and AHP (Triantaphyllou and Lin, 1996; Wang and Chang, 2007; Yang and Hung, 2007; Saremi et al., 2009; Zavadskas et al., 2010b).

Fuzzy set theory provides several forms of fuzzy numbers, such as trapezoidal, triangular and interval fuzzy numbers. Trapezoidal fuzzy numbers are the most general form of fuzzy numbers and triangular fuzzy numbers are probably the most frequently used ones. Interval fuzzy number is a special class of fuzzy numbers and a powerful tool to deal with uncertainty. Particularly, if there is not enough data to get a valid probability distribution, then the interval method is more applicable (Bao et al., 2010).

The MADM methods are often extended to allow the use of triangular or trapezoidal fuzzy numbers (Wang and Chang, 2007; Ertugrul and Karakasoglu, 2009), but there are 
also extensions which are formed with the aim of using fuzzy interval numbers (Jahanshahloo et al., 2006a; Zavadskas et al., 2010b).

The Multi-Objective Optimization on the basis of Ratio Analysis (MOORA) method is newly proposed method introduced by Brauers and Zavadskas (2006). Although the MOORA is a newly proposed method, it has been applied to solve many economic, managerial and construction problems. Chakraborty (2010) uses the MOORA method to solve different decision making problems in the real-time manufacturing environment. Kracka et al. (2010) applies the MOORA method in construction in order to solve problems related to energy loss in heating buildings. The aim of his research is to create a technique for the selection of external walls and windows of buildings. In the mentioned field Brauers and Zavadskas (Brauers and Zavadskas, 2009; Brauers et al., 2008b) use the MOORA method for evaluating contractors in the facilities sector. The MOORA method has also been successfully used for determining the best road design alternative (Brauers et al., 2008a).

The usage of the MOORA method in various fields of economy is proposed by Brauers and Zavadskas $(2010,2008)$ and Brauers and Ginevicius (2010, 2009). For example, Brauers and Zavadskas (2010) use the MOORA method for project management in a transaction economy, and Brauers and Ginevicious (2009) use the MOORA method to define the economic policy for balanced regional development in Lithuania.

According to the procedure used to rank alternatives, the MOORA method can be positioned between the well known SAW method and the most widely used TOPSIS method, which makes this method efficient and easy to use. However, since the MOORA method is newly proposed method, there are no proposed extensions for it. For these reasons, this paper proposes an extension of the MOORA method for its application with interval numbers.

The paper is organized as follows. Section 2 reviews the basic definitions and notions. Section 3 briefly introduces the MOORA method, where the ratio system part of the MOORA method is considered in Section 3.1 and its extension to deal with interval data is proposed in Section 3.2. Section 4 gives an example which illustrates the proposed approach. The conclusions are given in the final section.

\section{Basic Definitions and Notations}

In the rest of this section, we review some basic definitions of fuzzy sets and fuzzy numbers for the purpose of representing the proposed algorithm in Section 3.

Fuzzy sets. In order to deal with vagueness of human thought, Zadeh (1965) introduced the fuzzy set theory. In contrast to crisp sets that allow only full membership, an element belongs or does not belong to a set, fuzzy sets allow partial membership. Partial membership in fuzzy sets enables the formation of much realistic model of problems that will be solved by using MADM methods.

Fuzzy number. A real fuzzy number $A$ is described as a fuzzy subset of the real line $\Re$ with membership function $\mu_{A}$ that represents uncertainty. A membership function is defined from universe of discourse to $[0,1]$. 


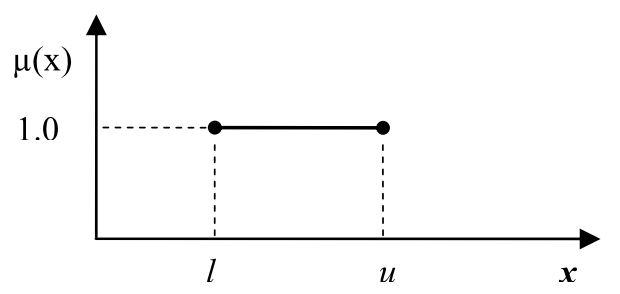

Fig. 1. Interval fuzzy number.

Interval Fuzzy Number (IFN). A interval fuzzy number is fully characterized by a pair of real numbers $(l, u)$, where $l$ and $u$ are the lower bound and the upper bound $(l, u$ $\in \Re ; l<u$ ). A interval fuzzy number $\bar{A}$ is shown on Fig. 1.

Membership function. The membership function $\mu_{\bar{A}}(x)$ of interval fuzzy number $\bar{A}$ is defined as:

$$
\mu(x)= \begin{cases}1, & x \in[l, u], \\ 0, & \text { otherwise }\end{cases}
$$

Fuzzy arithmetic operations. There are various arithmetic operations on interval fuzzy numbers. But here, the most important operations used in this study are illustrated. Let $\bar{A}=\left[a_{1}, a_{2}\right]$ and $\bar{B}=\left[b_{1}, b_{2}\right]$ be two positive interval fuzzy numbers. Then, the arithmetic operations on intervals are defined as is shown below (Moore, 1966):

Addition: $\quad \bar{A} \oplus \bar{B}=\left[a_{1}, a_{2}\right] \oplus\left[b_{1}, b_{2}\right]=\left(a_{1}+b_{1}, a_{2}+b_{2}\right)$.

Multiplication: $\bar{A} \otimes \bar{B}=\left[a_{1}, a_{2}\right] \otimes\left[b_{1}, b_{2}\right]=\left(a_{1} b_{1}, a_{2} b_{2}\right)$.

Multiplication by real number $k: \quad k \otimes \bar{A}=k \otimes\left[a_{1}, a_{2}\right]=\left[k a_{1}, k a_{2}\right]$.

Inverse interval: $\quad(\bar{A})^{-1}=\left[a_{1}, a_{2}\right]^{-1}=\left[1 / a_{2}, 1 / a_{1}\right]$.

Signed distance. Let $\bar{A}=\left[a_{1}, a_{2}\right]$ and $\bar{B}=\left[b_{1}, b_{2}\right]$ be two positive interval fuzzy numbers. Then, distance between $\bar{A}$ and $\bar{B}$ can be calculated as signed difference between its centers (Eberly, 2007), as is shown below:

$$
d(\bar{A}, \bar{B})=\frac{a_{1}+a_{2}}{2}-\frac{b_{1}+b_{2}}{2}=\frac{1}{2}\left[\left(a_{1}-b_{1}\right)+\left(a_{2}-b_{2}\right)\right] .
$$

\section{The MOORA Method}

As earlier mentioned, the MOORA is newly proposed method introduced by Brauers and Zavadskas (2006), after introducing its first part, the ratio system, in Brauers (2004).

The MOORA method consists of two components: the Ratio System and the Reference Point approach. The basic idea of the ratio system part of the MOORA method is to calculate the overall performance of each alternative as the difference between the 
sums of its normalized performances which belongs to benefit ${ }^{1}$ and $\operatorname{cost}^{2}$ criteria, by the formula:

$$
S_{i}=\sum_{j=1}^{g} r_{i j}-\sum_{j=g+1}^{n} r_{i j},
$$

where $r_{i j}$ is the normalized performance of $i$ th alternative with respect to $j$ th attribute, $g$ is the number of benefit attributes and $S_{i}$ is the overall performance index of $i$ th alternative with respect to all attributes.

Formula (7) does not provide a way for expressing different significance of attributes. However, when forming models that represent real-world problems, different attributes may have different significances. In order to express the different significance of attributes the Significance Coefficient was used (Brauers and Zavadskas, 2009; Brauers et al., 2010; Chakraborty, 2010), and (7) gets the following form:

$$
S_{i}=\sum_{j=1}^{g} w_{j} r_{i j}-\sum_{j=g+1}^{n} w_{j} r_{i j}
$$

where $w_{j}$ is significance coefficient (weight) of $j$ th attribute.

The proposed procedure for determining the overall performance is slightly more complex compared to the SAW method, which uses the following formula:

$$
S_{i}=\sum_{j=1}^{n} w_{j} r_{i j}
$$

However, the procedure applied in the SAW method does not distinguish between the benefit and cost criteria and therefore during the normalization process the cost criteria must be transformed into benefit criteria. That type of transformation is not always comfortable.

In relation to the TOPSIS method, where the overall performance of each alternative is calculated on its distance from the ideal and anti-ideal solution, the MOORA method provides a much simpler procedure for determining overall performance indexes.

\subsection{The Ratio System Part of the MOORA Method}

As in the case of using other MADM methods, the MOORA problem-solving procedure begins with the identification of available alternatives; by choosing the most important criteria; and by determining the criteria weights (significances). As a result of performing these activities the decision-making matrix $D$ can be formed.

After that, the remaining part of the MOORA method can be expressed concisely using the following steps:

${ }^{1}$ Criteria/attributes to be maximized, i.e., optimization direction is maximization.

${ }^{2} \mathrm{Criteria/attributes}$ to be minimized, i.e., optimization direction is minimization. 
Step 1: Calculate the normalized decision-making matrix. The normalized performance ratings $r_{i j}$ (Brauers and Zavadskas, 2006) are calculated as:

$$
r_{i j}=\frac{x_{i j}}{\sqrt{\sum_{i=1}^{m} x_{i j}^{2}}}
$$

Step 2: Calculate the weighted normalized decision-making matrix. Considering the different importance of criteria the weighted normalized ratings $v_{i j}$ are calculated as:

$$
v_{i j}=w_{j} \cdot r_{i j}
$$

Step 3: Calculate the overall ratings of benefit and cost criteria, for each alternative. The overall ratings of benefit criteria $S_{i}^{+}$are calculated as the sum of weighted normalized ratings of benefit criteria, using the following formula:

$$
S_{i}^{+}=\sum_{j=1}^{n} v_{i j} \mid j \in J^{\max } .
$$

where $J^{\max }$ is associated with benefit criteria.

Similarly, the overall ratings of cost criteria $S_{i}^{-}$are calculated as:

$$
S_{i}^{-}=\sum_{j=1}^{n} v_{i j} \mid j \in J^{\min }
$$

where $J^{m i n}$ is associated with cost criteria.

Step 4: Calculate the overall performance index $S_{i}$ for each alternative. The overall performance index of each alternative can be expressed as the differences between overall ratings of benefit and overall ratings of cost criteria, using the following formula:

$$
S_{i}=S_{i}^{+}-S_{i}^{-}
$$

Step 5: Rank alternatives and/or select the most efficient one. The considered alternatives are ranked by descending $S_{i}$, i.e., the alternatives with greater values of $S_{i}$ have a higher priority (rank). Determination of the most appropriate alternative $A^{*}$ can be done with the following formula:

$$
A^{*}=\left\{A_{i} \mid \max _{i} S_{i}\right\}
$$

\subsection{Extension of Ratio System Part of the MOORA Method for Solving Decision-Making Problems with Interval Data}

A systematic approach to extend the MOORA method to use interval data is proposed in this section. Suppose that $A_{1}, A_{2}, \ldots, A_{m}$ are $m$ possible alternatives among which 
decision makers have to choose, $C_{1}, C_{2}, \ldots, C_{n}$ are decision criteria used for evaluating alternatives, $x_{i j}$ is the performance rating of $i$ th alternative with respect to the $j$ th criterion. Suppose, also, that the performance ratings are not known exactly and we only know their minimum $x_{i j}^{\prime}$ and maximum $x_{i j}^{\prime \prime}$ values, which are also the lower and the upper boundaries of the closed intervals. Then $x_{i j} \in\left[x_{i j}^{\prime}, x_{i j}^{\prime \prime}\right]$, and a MADM problem with interval data can be concisely expressed in matrix format as:

$$
\begin{aligned}
& \begin{array}{llll}
C_{1} & C_{2} & \ldots & C_{n}
\end{array} \\
& D=\begin{array}{c}
A_{1} \\
A_{2} \\
\vdots \\
A_{m}
\end{array}\left[\begin{array}{cccc}
{\left[x_{11}^{\prime}, x_{11}^{\prime \prime}\right]} & {\left[x_{12}^{\prime}, x_{12}^{\prime \prime}\right]} & \ldots & {\left[x_{1 n}^{\prime}, x_{1 n}^{\prime \prime}\right]} \\
{\left[x_{21}^{\prime}, x_{21}^{\prime \prime}\right]} & {\left[x_{22}^{\prime}, x_{22}^{\prime \prime}\right]} & \ldots & {\left[x_{2 n}^{\prime}, x_{2 n}^{\prime \prime}\right]} \\
\vdots & \vdots & \vdots & \vdots \\
{\left[x_{m 1}^{\prime}, x_{m 1}^{\prime \prime}\right]} & {\left[x_{m 2}^{\prime}, x_{m 2}^{\prime \prime}\right]} & \ldots & {\left[x_{m n}^{\prime}, x_{m n}^{\prime \prime}\right]}
\end{array}\right] \\
& W=\left[w_{1}, w_{2}, \ldots, w_{n}\right] \text {. }
\end{aligned}
$$

Then, the MOORA method can be expressed concisely using the following steps:

Step 1: Calculate the normalized decision-making matrix. The authors of MOORA method (Brauers and Zavadskas, 2006) propose the use of the vector normalization procedure. The procedures used for normalizing the decision-making matrix whose values are intervals are more complex compared to the procedures used for crisp values. For normalization of the intervals, Jahanshahloo et al. (2006a) suggested using the following formulas:

$$
\begin{aligned}
& r_{i j}^{\prime}=\frac{x_{i j}^{\prime}}{\sqrt{\sum_{i=1}^{m}\left(x_{i j}^{\prime}\right)^{2}+\left(x_{i j}^{\prime \prime}\right)^{2}}}, \\
& r_{i j}^{\prime \prime}=\frac{x_{i j}^{\prime \prime}}{\sqrt{\sum_{i=1}^{m}\left(x_{i j}^{\prime}\right)^{2}+\left(x_{i j}^{\prime \prime}\right)^{2}}},
\end{aligned}
$$

where $r_{i j}^{\prime}$ are the normalized lower and $r_{i j}^{\prime \prime}$ are the normalized upper performance ratings.

Step 2: Calculate the weighted normalized interval decision-making matrix. To calculate the weighted normalized ratings, in the case of intervals, the following formulas are used:

$$
\begin{aligned}
& v_{i j}^{\prime}=w_{j} \cdot r_{i j}^{\prime}, \\
& v_{i j}^{\prime \prime}=w_{j} \cdot r_{i j}^{\prime \prime} .
\end{aligned}
$$

where $v_{i j}^{\prime}$ and $v_{i j}^{\prime \prime}$ are the lower and upper bounds of weighted normalized intervals.

Step 3: Calculate the overall ratings of benefit and cost criteria, for each alternative. When intervals are used, the overall ratings are also intervals, limited with its smallest and lowest values. Therefore, to calculate the lower and the upper limits of the intervals which represent the overall rating of benefit criteria $S_{i}^{+}$, the following formulas are used:

$$
s_{i}^{+l}=\sum_{j=1}^{n} v_{i j}^{\prime} \mid j \in J^{\max },
$$




$$
s_{i}^{+u}=\sum_{j=1}^{n} v_{i j}^{\prime \prime} \mid j \in J^{\max } .
$$

where $s_{i}^{+l}$ and $s_{i}^{+u}$ are the values of lower and upper limits of intervals respectively.

Similarly, the overall rating of cost criteria $S_{i}^{-}$, or more precisely its lower and upper limit, are calculated using the following formulas:

$$
\begin{aligned}
& s_{i}^{-l}=\sum_{j=1}^{n} v_{i j}^{\prime} \mid j \in J^{\mathrm{min}}, \\
& s_{i}^{-u}=\sum_{j=1}^{n} v_{i j}^{\prime \prime} \mid j \in J^{\mathrm{min}} .
\end{aligned}
$$

where $s_{i}^{-l}$ and $s_{i}^{-u}$ are values of lower and upper bounds of intervals.

Step 4: Calculate the overall performance index $S_{i}$, for each alternative. As a result of performing the previous steps, overall performance ratings obtained on the basis of benefit and cost criteria are intervals. Therefore, based on a formula (6) crisp valued overall performance index $S_{i}$, for each alternative, can be calculated using the following formula:

$$
S_{i}\left(S_{i}^{+}, S_{i}^{-}\right)=\frac{1}{2}\left[\left(s_{i}^{+l}-s_{i}^{-l}\right)+\left(s_{i}^{+u}-s_{i}^{-u}\right)\right] .
$$

Step 5: Rank alternatives and/or select the most efficient one. Ranking alternatives and/or selecting the most efficient one is based on the values of $S_{i}$, as well as in the original MOORA method.

\section{A Numerical Example}

In this section, we consider a numerical example in order to explain the proposed approach. The numerical example of Contractors selection in construction, presented in Zavadskas et al. (2009b), is applied to illustrate the feasibility of the proposed model. The selected criteria, criteria weights and optimization directions are shown in Table 1.

The normalized values are calculated applying (16) and (17). Then normalized decision-making matrix is presented in Table 2 . In the normalized matrix all the values are in the interval $[0 ; 1]$.

The weighted normalized values (Table 3) are calculated applying (18) and (19).

The weighted-normalized decision-making matrix enables to calculate the overall performances of benefit and overall performances of cost criteria for considered alternative.

The boundaries of the interval which represent the overall rating of benefit criteria are calculated by (20) and (21). Similarly, the boundaries of the interval which represent the overall rating of cost criteria are calculated by (22) and (23). Results obtained using these formulas are presented in Table 4. 
Table 1

Initial decision-making matrix with values expressed in intervals

\begin{tabular}{|c|c|c|c|c|c|c|c|c|}
\hline & \multicolumn{8}{|c|}{ Criteria } \\
\hline & \multicolumn{2}{|c|}{ Technical } & \multicolumn{2}{|c|}{ Financial } & \multicolumn{2}{|c|}{$\begin{array}{l}\text { Integrated contractual } \\
\text { and administrative }\end{array}$} & \multicolumn{2}{|c|}{$\begin{array}{l}\text { Time of } \\
\text { the projec }\end{array}$} \\
\hline Optimization & \multicolumn{2}{|c|}{$\max$} & \multicolumn{2}{|c|}{$\max$} & \multicolumn{2}{|c|}{$\max$} & \multicolumn{2}{|c|}{$\min$} \\
\hline \multirow[t]{2}{*}{$w_{i}$} & 0.15 & & 0.4 & & 0.2 & & & \\
\hline & \multicolumn{2}{|l|}{$C_{1}$} & \multicolumn{2}{|c|}{$C_{2}$} & \multicolumn{2}{|l|}{$C_{3}$} & \multicolumn{2}{|l|}{$C_{4}$} \\
\hline Contractors & & $u_{1}$ & & $u_{2}$ & $\overline{l_{3}}$ & $u_{3}$ & $\bar{l} l_{4}$ & $u_{4}$ \\
\hline$A_{1}$ & 64 & 85 & 50 & 55 & 60 & 80 & 75 & 80 \\
\hline$A_{2}$ & 57 & 81 & 52 & 56 & 62 & 76 & 70 & 75 \\
\hline$A_{3}$ & 61 & 78 & 55 & 58 & 53 & 61 & 70 & 75 \\
\hline$A_{4}$ & 59 & 93 & 54 & 62 & 55 & 72 & 80 & 90 \\
\hline$A_{5}$ & 63 & 89 & 61 & 68 & 54 & 63 & 65 & 78 \\
\hline
\end{tabular}

Table 2

Normalized decision-making matrix

\begin{tabular}{|c|c|c|c|c|c|c|c|c|}
\hline \multirow{3}{*}{$\begin{array}{l}\text { Optimization } \\
w_{i}\end{array}$} & \multicolumn{8}{|c|}{ Criteria } \\
\hline & \multirow{2}{*}{\multicolumn{2}{|c|}{$\begin{array}{l}\max \\
0.15\end{array}$}} & \multicolumn{2}{|l|}{$\max$} & \multicolumn{2}{|l|}{$\max$} & \multicolumn{2}{|l|}{$\min$} \\
\hline & & & 0.4 & & 0.2 & & 0.25 & \\
\hline \multirow[b]{2}{*}{ Contractors } & \multicolumn{2}{|l|}{$C_{1}$} & \multicolumn{2}{|l|}{$C_{2}$} & \multicolumn{2}{|l|}{$C_{3}$} & \multicolumn{2}{|l|}{$C_{4}$} \\
\hline & $l_{1}$ & $u_{1}$ & $\overline{l_{2}}$ & $u_{2}$ & $l_{3}$ & $u_{3}$ & $\overline{l_{4}}$ & $u_{4}$ \\
\hline$A_{1}$ & 0.273 & 0.363 & 0.276 & 0.303 & 0.295 & 0.394 & 0.312 & 0.333 \\
\hline$A_{2}$ & 0.243 & 0.346 & 0.287 & 0.309 & 0.305 & 0.374 & 0.291 & 0.312 \\
\hline$A_{3}$ & 0.260 & 0.333 & 0.303 & 0.320 & 0.261 & 0.300 & 0.291 & 0.312 \\
\hline$A_{4}$ & 0.252 & 0.397 & 0.298 & 0.342 & 0.271 & 0.355 & 0.333 & 0.374 \\
\hline$A_{5}$ & 0.269 & 0.380 & 0.337 & 0.375 & 0.266 & 0.310 & 0.270 & 0.324 \\
\hline
\end{tabular}

Table 3

The weighted-normalized decision-making matrix

\begin{tabular}{|c|c|c|c|c|c|c|c|c|}
\hline \multirow[b]{2}{*}{ Optimization } & \multicolumn{8}{|c|}{ Criteria } \\
\hline & $\max$ & & $\max$ & & $\max$ & & $\min$ & \\
\hline \multirow[b]{2}{*}{ Contractors } & \multicolumn{2}{|l|}{$C_{1}$} & \multicolumn{2}{|l|}{$C_{2}$} & \multicolumn{2}{|l|}{$C_{3}$} & \multicolumn{2}{|l|}{$C_{4}$} \\
\hline & $l_{1}$ & $u_{1}$ & $l_{2}$ & $u_{2}$ & $l_{3}$ & $u_{3}$ & $l_{4}$ & $u_{4}$ \\
\hline$A_{1}$ & 0.041 & 0.054 & 0.110 & 0.121 & 0.059 & 0.079 & 0.078 & 0.083 \\
\hline$A_{2}$ & 0.036 & 0.052 & 0.115 & 0.124 & 0.061 & 0.075 & 0.073 & 0.078 \\
\hline$A_{3}$ & 0.039 & 0.050 & 0.121 & 0.128 & 0.052 & 0.060 & 0.073 & 0.078 \\
\hline$A_{4}$ & 0.038 & 0.060 & 0.119 & 0.137 & 0.054 & 0.071 & 0.083 & 0.094 \\
\hline$A_{5}$ & 0.040 & 0.057 & 0.135 & 0.150 & 0.053 & 0.062 & 0.068 & 0.081 \\
\hline
\end{tabular}


Table 4

The ranking results obtained using the MOORA method

\begin{tabular}{|c|c|c|c|c|c|c|}
\hline \multirow[t]{2}{*}{ Contractor } & \multicolumn{2}{|l|}{$\underline{S^{+}}$} & \multicolumn{2}{|l|}{$S^{-}$} & \multirow[t]{2}{*}{$S$} & \multirow[t]{2}{*}{ Rank } \\
\hline & $\bar{l}$ & $u$ & $l$ & $u$ & & \\
\hline$A_{1}$ & 0.210 & 0.255 & 0.078 & 0.083 & 0.152 & 3 \\
\hline$A_{2}$ & 0.212 & 0.250 & 0.073 & 0.078 & 0.156 & 2 \\
\hline$A_{3}$ & 0.213 & 0.238 & 0.073 & 0.078 & 0.150 & 5 \\
\hline$A_{4}$ & 0.211 & 0.267 & 0.083 & 0.094 & 0.151 & 4 \\
\hline$A_{5}$ & 0.228 & 0.269 & 0.068 & 0.081 & 0.174 & 1 \\
\hline
\end{tabular}

And finally, the overall performance index $S_{i}$ for each alternative is calculated using (24) and also presented in Table 4.

According to the calculation results, ranking order of alternatives is as follows: $A_{5} \succ$ $A_{2} \succ A_{1} \succ A_{4} \succ A_{3}$.

This means that the last alternative, $A_{5}$, is the best solution with the overall performance index of 0.174 , and the third alternative, $A_{3}$, is the worst with the result of 0.150 .

Results obtained using the proposed methodology is very similar to the results published in the original paper Zavadskas et al. (2009b), when COPRAS-G method is used. In mentioned paper, as the best alternative is also chosen alternative $A_{5}$, and the ranking order of alternatives was been as follows: $A_{5} \succ A_{2} \succ A_{1}=A_{4} \succ A_{3}$.

These results confirm the correctness of the proposed methodology.

\section{Conclusion}

Solving many real-world problems requires the use of some form of fuzzy numbers.

Although they represent the simplest form of fuzzy numbers, interval fuzzy numbers can be very useful for solving problems that manifest themselves in a semi structured or unstructured areas, because this form of the interval fuzzy numbers requires only determination of minimum and maximum values, i.e., the boundaries of intervals.

The MOORA method is recently published method, which is characterized by a relatively efficient and easy-to-understand approach, logically based procedure for selecting the most appropriate alternative or ranking available alternatives. As shown in this paper the Ratio system part of MOORA method can be easily extended to provide usage of the interval fuzzy numbers, which would allow its use for solving a much larger number of real problems.

Acknowledgements. This paper is a partial result of the project TR33023 financed by the Ministry of Science and Technological Development of Republic of Serbia. The constructive comments of the referees are gratefully acknowledged. 


\section{References}

Bao, F., Zhu, P.P., Zhao, P.B. (2010). Portfolio selection problems based on fuzzy interval numbers under the Minimax rules. International Journal of Mathematical Analysis, 4(1), 2143-2166.

Bellman, R.E., Zadeh, L.A. (1970). Decision-making in a fuzzy environment. Management Science, 17(4), $141-164$.

Brans, J.P., Vincke, P. (1985). A preference ranking organization method: the PROMETHEE method for MCDM. Management Science, 31(6), 647-656.

Brauers, W.K.M. (2004). Optimization Methods for a Stakeholder Society: A Revolution in Economic Thinking by Multiobjective Optimization. Kluwer Academic, Boston.

Brauers, W.K.M., Ginevicius, R. (2009). Robustness in regional development studies: the case of Lithuania. Journal of Business Economics and Management, 10(2), 121-140.

Brauers, W.K.M., Ginevicius, R. (2010). The economy of the Belgian regions tested with MULTIMOORA. Journal of Business Economics and Management, 11(2), 173-209.

Brauers, W.K.M., Zavadskas, E.K. (2006). The MOORA method and its application to privatization in transition economy. Control and Cybernetics, 35(2), 443-468.

Brauers, W.K.M., Zavadskas, E.K. (2008). Multi-objective optimization in local theory with a simulation for a department store. Transformations in Business \& Economics, 7 (3), 163-183.

Brauers, W.K.M., Zavadskas, E.K. (2009). Robustness of the multi-objective MOORA method with a test for the facilities sector. Technological and Economic Development of Economy, 15(2), 352-375.

Brauers, W.K.M., Zavadskas, E.K. (2010). Project management by MULTIMOORA as an instrument for transition economies. Technological and Economic Development of Economy, 16(1), 5-24.

Brauers, W.K.M., Zavadskas, E.K., Peldschus, F., Turskis, Z. (2008a). Multi-objective decision-making for road design. Transport, 23(3), 183-193.

Brauers, W.K.M., Zavadskas, E.K., Turskis, Z., Vilutiene, T. (2008b). Multi-objective contractor's ranking by applying the MOORA method. Journal of Business Economics and Management, 9(4), 245-255.

Brauers W.K.M., Ginevicius, R., Podvezko, V. (2010). Regional development in Lithuania considering Multiple Objectives by the MOORA method. Technological and Economic Development of Economy, 16(4), 613-640.

Buckley, J., Qu, Y. (1990). On using $\alpha$-cuts to evaluate fuzzy equations. Fuzzy Sets and Systems, 38(1), 309312.

Carlsson, C., Fuller, R. (1996). Fuzzy multiple criteria decision-making: recent development. Fuzzy Sets and Systems, 78(1), 139-153.

Chakraborty, S. (2010). Application of the MOORA method for decision making in manufacturing environment. The International Journal of Advanced Manufacturing Technology, 54(9-12), 1155-1166.

Chen, C.T. (2000). Extensions of the TOPSIS for group decision-making under fuzzy environment. Fuzzy Sets and Systems, 114(1), 1-9.

Chen, C.B., Klein, C.M. (1997). An efficient approach to solving fuzzy MADM problems. Fuzzy Sets and Systems, 88(1), 51-67.

Dong, W., Shah, H. (1987). Vertex method for computing functions on fuzzy variables. Fuzzy Sets and Systems, $24,65-78$.

Eberly, D.H. (2007). 3D Game Engine Design: A Practical Approach to Real-Time Computer Graphics. Gulf Professional Publishing.

Ertugrul, I., Karakasoglu, N. (2009). Performance evaluation of turkish cement firms with fuzzy analytic hierarchy process and TOPSIS methods. Expert Systems with Applications, 36(1), 702-715.

Guo, P.,Tanaka, H., Inuiguchi, M. (2000). Self-organizing fuzzy aggregation models to rank the objects with multiple attributes. IEEE Transactions on Systems, Man, and Cybernetics, 30(5), 573-580.

Hwang, C.L., Yoon, K. (1981). Multiple Attribute Decision Making - Methods and Applications. Springer, New York.

Jahanshahloo, G.R., Hosseinzadeh, L.F., Izadikhah, M.V. (2006a). An algorithmic method to extend TOPSIS for decision-making problems with interval data. Applied Mathematics and Computation, 175(1), 1375-1384.

Jahanshahloo, G.R., Lotfi, F.H., Izadikhah, M. (2006b). Extension of the TOPSIS method for decision-making problems with fuzzy data. Applied Mathematics and Computation, 181(2), 1544-1551.

Kaklauskas, A., Zavadskas, E.K., Naimaviciene, J., Krutinis, M., Plakys, V., Venskus, D. (2010). Model for a complex analysis of intelligent built environment. Automation in Construction, 19(3), 326-340.

Kracka, M., Brauers, W.K.M., Zavadskas, E.K. (2010). Ranking heating losses in a building by applying the 
MULTIMOORA. Inzinerine Ekonomika - Engineering Economics, 21(4), 352-359.

MacCrimon, K.R. (1968). Decision marking among multiple-attribute alternatives: a survey and consolidated approach. RAND memorandum, RM-4823-ARPA. The Rand Corporation, Santa Monica.

Moore, R.E. (1966). Interval Analysis. Prentice-Hall, New Jersey.

Opricovic, S. (1998). Multicriteria Optimization of Civil Engineering Systems. Faculty of Civil Engineering, Belgrade (in Serbian).

Opricovic, S., Tzeng, G.H. (2003). Defuzzification within a fuzzy multicriteria decision model. International Journal of Uncertainty, Fuzziness and Knowledgebased Systems, 11(5), 635-652.

Peldschus, F. (2009). The analysis of the quality of the results obtained with the methods of multi-criteria decisions. Technological and Economic Development of Economy, 15(4), 580-592.

Peldschus, F., Zavadskas, E.K., Turskis, Z., Tamosaitiene, J. (2010). Sustainable assessment of construction site by applying game theory. Inzinerine Ekonomika-Engineering Economics, 21(3), 223-237.

Roy, B. (1991. The outranking approach and the foundation of ELECTRE methods. Theory and Decision 31(1), 49-73.

Saaty, T.L. (1980). Analytic Hierarchy Process: Planning, Priority Setting, Resource Allocation. McGraw-Hill, New York.

Saremi, M., Mousavi, S.F., Sanayei, A. (2009). TQM consultant selection in SMEs with TOPSIS under fuzzy environment. Expert Systems with Applications, 36(1), 2742-2749.

Triantaphyllou, E., Lin C.T. (1996). Development and evaluation of five fuzzy multiattribute decision-making methods. International Journal of Approximate Reasoning, 14(4), 281-310.

Wang, T.C., Chang, T.H. (2007). Application of TOPSIS in evaluating initial training aircraft under a fuzzy environment. Expert Systems With Applications, 33(4), 870-880.

Yang, T., Hung, C.C. (2007). Multiple-attribute decision making methods for plant layout design problem. Robotics and Computer-Integrated Manufacturing, 23(1), 126-137.

Yoon, K., Hwang, C.L. (1995). Multiple attribute decision making: An introduction. Sage Publications, London. Zadeh, L.A. (1965). Fuzzy sets. Information and Control, 8(1), 338-353.

Zavadskas, E.K., Turskis, Z. (2010). A new additive ratio assessment (ARAS) method in multicriteria decisionmaking. Technological and Economic Development of Economy, 16 (2), 159-172.

Zavadskas, E.K., Kaklauskas, A., Sarka, V. (1994). The new method of multicriteria complex proportional assessment of projects. Technological and Economic Development of Economy, 1(3), 131-139.

Zavadskas, E.K., Kaklauskas, A., Vilutiene, T. (2009a). Multicriteria evaluation of apartment blocks maintenance contractors: Lithuanian case study. International Journal of Strategic Property Management, 13(4), 319-338.

Zavadskas, E.K., Kaklauskas, A., Turskis, Z., Tamosaitiene, J. (2009b). Multi-attribute decision-making model by applying grey numbers. Informatica, 20(2), 305-320.

Zavadskas, E.K., Turskis, Z., Vilutiene, T. (2010a). Multiple criteria analysis of foundation instalment alternatives by applying Additive Ratio Assessment (ARAS) method. Archives of Civil and Mechanical Engineering, 10(3), 123-141.

Zavadskas, E.K., Vilutiene, T., Turskis, Z., Tamosaitiene, J. (2010b). Contractor selection for construction works by applying SAW-G and TOPSIS grey techniques. Journal of Business Economics and Management, 11(1), 34-55. 
D. Stanujkić was born in Zajecar, Serbia, in 1964. He received his BSc degree in mechanical engineering from the Technical Faculty of Bor, Serbia, in 1988, and MSc degree in information systems from the Faculty of Organizational Sciences, the University of Belgrade, in 1993. He received his PhD degree from the University of Belgrade, also in 2008. He is currently working as a docent at the Department of Information Technology at the Faculty of Management in Zajecar, Megatrend University Belgrade, Serbia. His current research interests include decision-making theory, expert systems and intelligent decision support systems.

N. Magdalinović is the dean of the Faculty of Management Zajecar, Megatrend University Belgrade, Serbia. He has a $\mathrm{PhD}$ in mineral technologies, obtained in $1979 . \mathrm{He}$ is a regular member of the Balkan Academy of Sciences of Mineral Technologies and a member of the Academy of Engineering Sciences of Serbia. His current research interests include decision-making theory, project management and technological processes of preparing and concentrating mineral raw materials.

S. Stojanovic was born in Bor, Serbia, in 1975. She received her BSc degree in computer and mathematical sciences at the Faculty of Natural Sciences in Nis, Serbia, in 1999, as the best student in her generation class. MSc degree received in 2009, in economics at the Faculty of Management in Zajecar, Megatrend University Belgrade, Serbia. Her current research interests include decision making theory, econometric, business statistics and project management.

R. Jovanović was born in Zajecar, Serbia, in 1946. He received his BSc degree in mineral technologies at the Faculty of Mining and Metallurgy of Bor, Serbia, in 1973, and MSc degree in economics at Megatrend University - Belgrade, in 2005. He received his PhD degree also at Megatrend University, in 2007. He is currently working as a docent at the Department of Production Management at the Faculty of Management in Zajecar, Megatrend University Belgrade, Serbia. His current research interests include production management in complex manufacturing systems, with special interest in production of copper ore concentrate.

\title{
Sprendimu prièmimas MOORA metodu papildant santykiu sistemos algoritma intervalais
}

\author{
Dragisa STANUJKIC, Nedeljko MAGDALINOVIC, Sanja STOJANOVIC, \\ Rodoljub JOVANOVIC
}

Kai kuriais atvejais naudojant daugiatikslius sprendimų prièmimo metodus sprendžiant realias pasaulio problemas alternatyvụ rangai negali būti apibrèžti tiksliai, todèl išreiškiami intervalais. Šio straipsnio tikslas pritaikyti MOORA metodą sprendžiant sprendimu prièmimo problemas naudojant intervalus. Straipsnyje praplečiamas MOORA metodo santykiu sistemos algoritmas, kuris nustato labiausiai pageidautiną alternatyvą tarp visu galimų alternatyvų, kai charakteringasis rangas apibrěžiamas intervalu. Galiausiai, straipsnyje pateikiamas pavyzdys, kuriame apibrež̌iama siūloma procedūra. 